Donna Bernardo-Ceriz

\title{
A Jewish Tale of Suburbia: Bathurst Manor
}


How does one tell the story of a neighbourhood? If examining the changing and developing physical landscape, then records are in no short supply at various government archives: census records, municipal planning records, maps, assessment roles, directories, building surveys, and aerial photographs, to name only a few. Retelling the experiences of a community of people, however, requires a slightly different research strategy. Personal papers, photographs, letters, home movies, and oral histories offer a glimpse into the lives of residents. Organizational records can provide insight into the cultural, religious, and social needs of a community and the services offered. But what if those records do not exist or cannot easily be located?

The Ontario Jewish Archives (OJA) receive over 650 research requests each year. If we divide that by the number of working days (ignoring vacations, stat, and Jewish holidays), that equals 2.5 inquiries every day. Some of these inquiries are fairly quick and straightforward, and some are long, protracted research endeavours. We also receive over 50,000 unique users to our website each year; researchers whom we never interact with and whose research we never hear about. Of these research requests, a sizable number are related to Jewish spaces and shifting landscapes.

"I'm researching the history of Kensington Market"; "Do you have any records on The Ward?"; "I'd like to study the small communities in Ontario"; "I'm interested in how Bathurst Street became the spine of Toronto's Jewish community." While these questions may appear well defined, it is the archivist's job to determine what the researcher is actually asking. Most times, they are seeking a better understanding of the lived experiences of these neighbourhoods. What attracted Jews to move there? What were the push/pull factors? What were the benefits and limitations? How did residents tend to their specific cultural and/or religious needs? How did people create a sense of community from nothing? What made these environments uniquely Jewish? These are all important questions in understanding how Jewish communal life is formed and reformed across time and space.

And while the appetite for Toronto's Kensington Market may never be sated, interest has more recently begun to shift to suburbia and neighbourhoods like Bathurst Manor, a Jewish enclave teetering on the north edge of Toronto. For those who know Toronto, the area is bounded by Sheppard Avenue to the south, Dufferin Street to the west, Bathurst Street to the east, and the west Don Valley tributary to the north, a natural meandering boundary that cuts diagonally across from Bathurst to Finch Avenue, an intrusion into the otherwise grid-like layout of the neighbourhood.

In the early 1950s, Toronto's downtown Jewish community began its move north up Bathurst Street, predominantly from Kensington Market and its surrounding environs, as well as midtown pockets around St. Clair and Eglinton Avenues. This postwar demographic shift paralleled what was happening in other suburban neigh- 
bourhoods in Toronto but had a markedly Jewish emphasis in Bathurst Manor.

Recently arrived Holocaust survivors and second-generation Kensington Market residents were drawn by the promises of the suburban landscape: space, peace and quiet, affordability, modernity, and an upwardly mobile lifestyle. Real estate agents promised "a home tailored for you in a community designed for tomorrow."

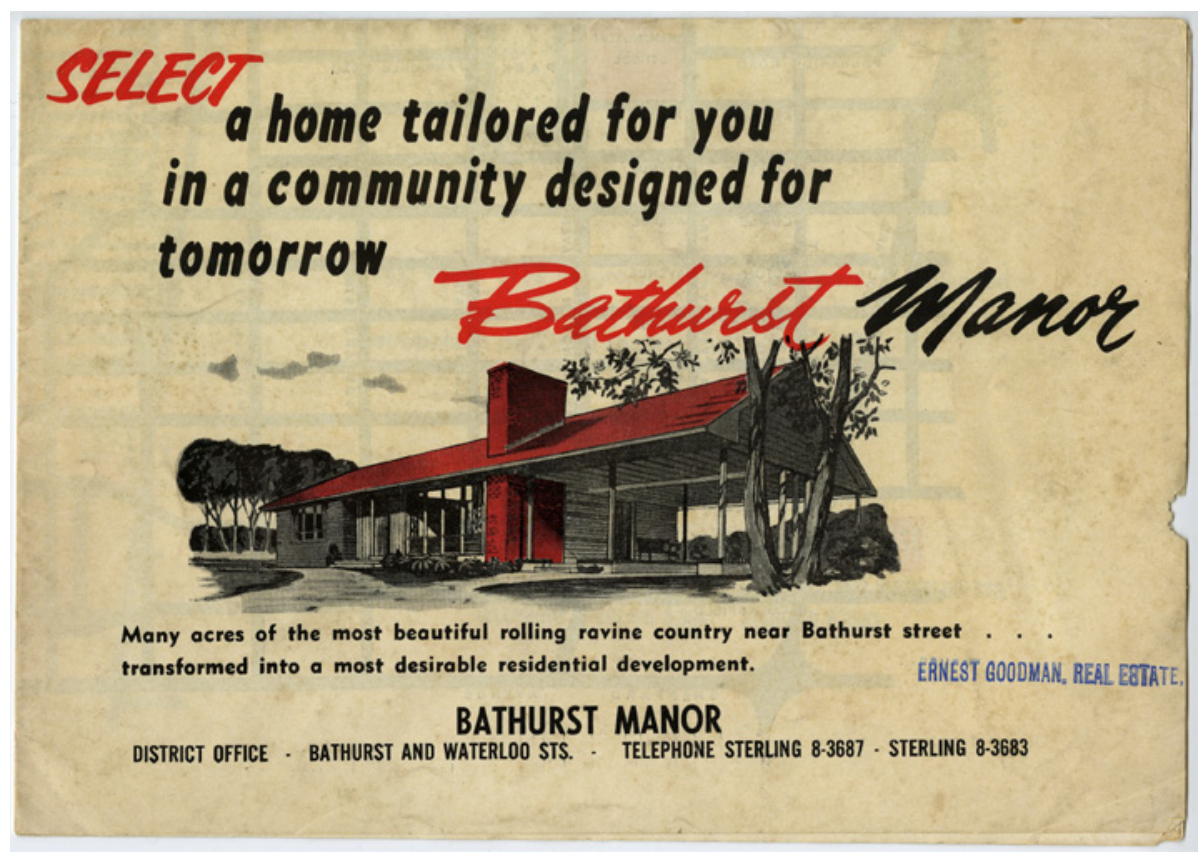

Promotional leaflet for Bathurst Manor, c1955. Judy Kasman collection. Ontario Jewish Archives, Blankenstein Family Heritage Centre, accession 2020-2-4.

By 1956, development of Bathurst Manor was well underway, transitioning the former farmland into a suburban community of ranch-style houses, bungalows, and side-split single-family homes. Pioneering homeowners loved the generous lots and the quiet, orderly streets. The houses even had basements that could be let out to tenants to support the inevitable mortgage payments. Like many suburbs, the Manor was built in stages. Developers bought small tracts of land, severed them into lots, and built a few houses that would fund the purchase of more land and more houses. Clanton Park, another largely Jewish suburb to the south, predated the Manor by a few short years and may have provided the motivation for further development north of Sheppard.

According to the 196I Canadian census, between 1956 and 196I the population of Bathurst Manor rose from I,953 residents to 9,27I, an increase of $375 \%$ in five short 
years. Of these over 9,200 residents, 7,093 were recorded as Jewish. Of the total population, I,764 residents had immigrated between 1946 and I96I, suggesting that nearly I in 5 residents were either Holocaust survivors or other displaced persons. While the Jewish population grew by only 800 by 1971, the number of residents who had immigrated after 1945 rose by 1,000 .

As more residents moved in and several downtown synagogues, businesses, and cultural organizations followed, the Manor soon became a lively Jewish enclave with shops, parks, schools, and shuls that served multiple generations of Canadian-born and Holocaust survivor families.

While the OJA has a respectable amount of archival material documenting other Jewish settlement areas in Toronto and a cross-section of their residents, at the start of this project our holdings were comparatively small for Bathurst Manor. Perhaps unsurprisingly, the largest groupings of records were those of the synagogues and organizations situated within its boundaries. Congregational records made up the bulk of the material (Beth Emeth Bais Yehuda, Lodzer Centre), supplemented by organizational records from groups operating out of the Borochov Centre (Labour Zionist Order, Na'amat) and records of the northern Young Men's Hebrew Association (YMHA)/Bathurst Jewish Community Centre. Largely missing were the personal papers reflecting the lived experiences of Jewish suburbia and expressions of family life. Although never completely absent, these perspectives are often harder to capture in organizational records.

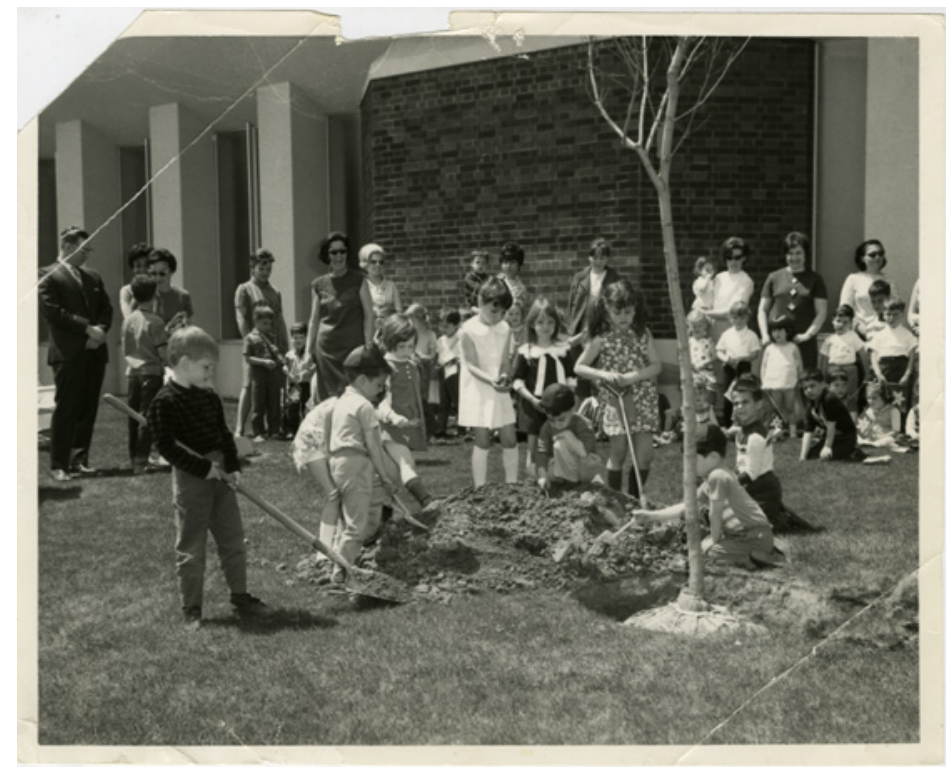

Tree planting at Beth Emeth Synagogue, 196-. Rabbi Joseph Kelman collection. Ontario Jewish Archives, Blankenstein Family Heritage Centre, accession 2012-2-1. 
The aim of the Bathurst Manor project, therefore, is first to recognize the historical importance of this neighbourhood deserving of preservation, and second to begin filling in the archival gaps. By engaging the community and collecting the evidence of individuals who lived and worked in the Manor, the hope is to provide future researchers with the resources required to explore and understand this particular Jewish landscape from multiple viewpoints.

Targeted collection development projects can quickly become tactical nightmares if not well planned and executed. They tend to blur the line between research project and collecting initiative and as a result have historically been the domain of community and activist archives. Rather than simply acknowledging gaps and prejudiced collecting practices, community archives are often more aggressive in addressing them-networking, forming new relationships, engaging ambassadors and advocates, conducting oral histories, and widening the focus beyond a few key acquisitions to welcome all donations, big and small. In addition, there are often related programming and a final share-back piece, to keep the community engaged over the long haul and reflect back the experiences that donors have shared. For targeted initiatives like the Manor, thought needs to go into a number of areas: What exactly are we trying to document? What stories are missing? Whom do we need to reach? How do we ensure that the collections represent a diversity of voices?

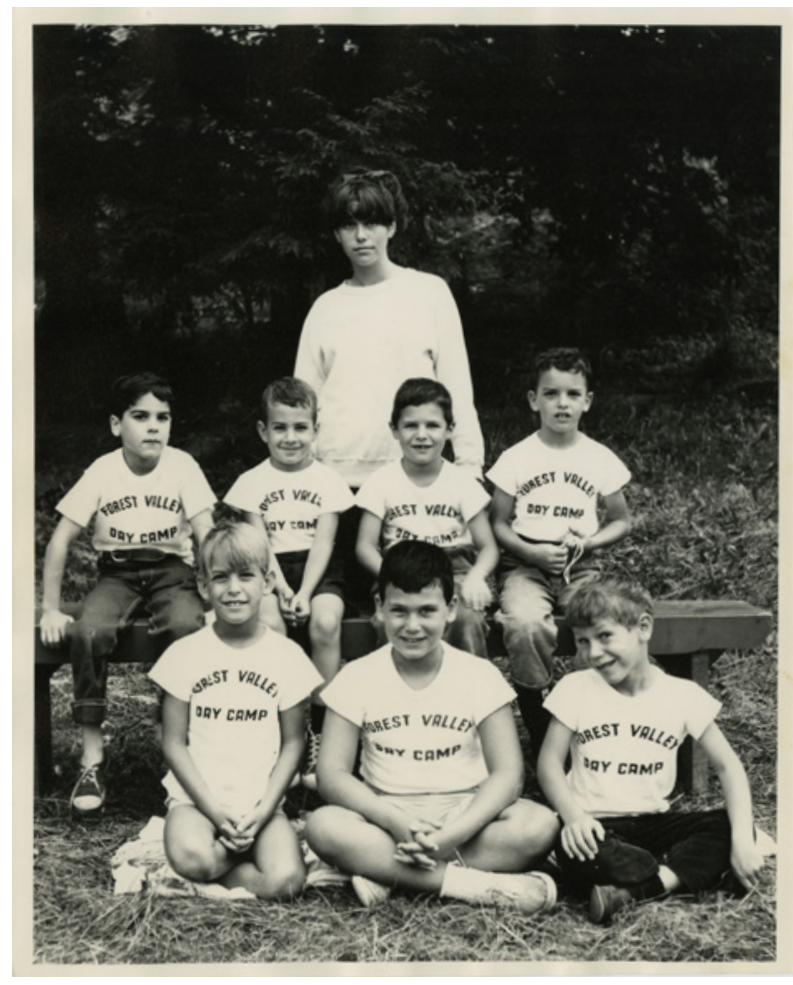

Forest Valley Day Camp, ca. 1965. Ontario Jewish Archives, Blankenstein Family Heritage Centre, accession 2020-3-4. 
The benefit of focusing on the Manor right now is that many of its first residents are still with us to tell their stories. In February 2020, the OJA began by convening a small focus group of current and former residents to help provide structure to the project. Over coffee and sweets, the focus group engaged in two self-reflecting exercises, both designed to capture participant impressions of the neighbourhood and pinpoint some of the important themes and landmarks from their time in the Manor.

Each activity encouraged the participants to reflect on why their family had moved to the Manor. Responses varied, but many commonalities emerged. Some felt like pioneers, noting that the neighbourhood felt more rural than urban with ditches, farmland, and unpaved roads. More than one participant mentioned feeling disconnected from the rest of the city, a feeling that was accentuated by having to pay a double fare on the city bus to travel north of Lawrence Avenue, what is now considered Toronto's midtown.

Several participants reflected on how they spent their leisure time, such as going to the Jewish YMHA, which opened in I96I and by 1962 had a membership of over 8,ooo. Bert Fine's Bathurst Manor/Forest Valley Day Camp was mentioned by several participants with overwhelming fondness as was the Bathurst Manor baseball league. Wilmington Plaza (also known as Sunnybrook and Bathurst Manor Plaza) and its many shops and services that served the predominantly Jewish community were noted as important central hubs-Stan Cribby's cigar store in particular-alongside the schools and synagogues that serviced the community. Participants also spoke of the unique physical landscape of the Manor and nearby features such as the ravine, or specific streets, often within a small radius of their family homes.

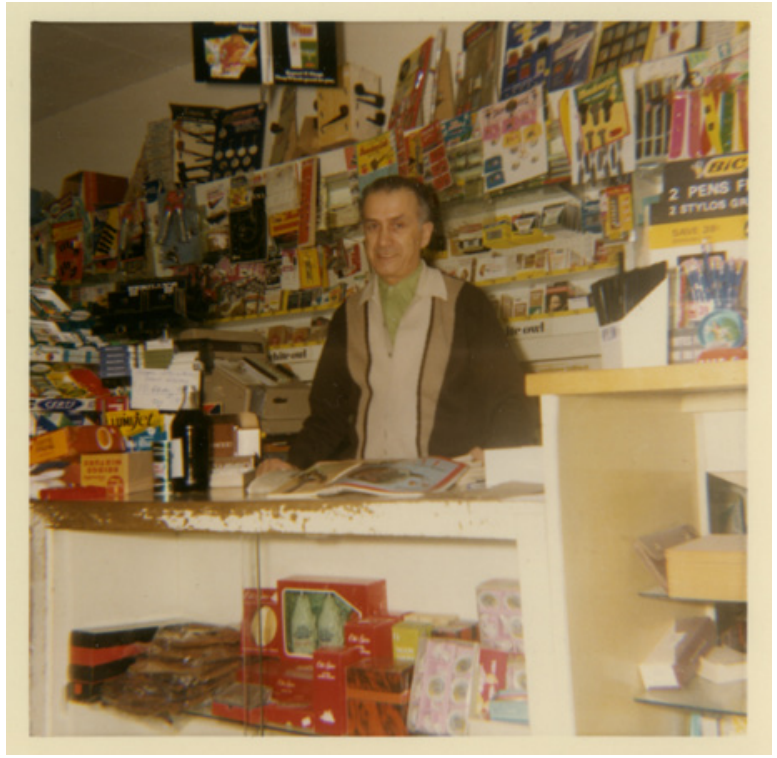

David Herman (successor to Stan Cribby) behind the counter in the Cigar Store, Bathurst Manor Plaza, 1972. Blum family collection. Ontario Jewish Archives, Blankenstein Family Heritage Centre, accession 2017-2-1. 
The focus group also spoke candidly about the distorted view that living in the Manor created of the Jewish population as a whole. The density of Jewish residents meant that some participants never recognized themselves as "other" until well into their teen years or later. Others spoke about the complexity that lurked beneath the tranquility of suburbia. For those who grew up there, it was well known that Bathurst Manor was home to many Holocaust survivors, and the census numbers support that impression. While participants had differing views on the amount of division within the community, one respondent remarked that in the Manor intermarriage was a reference to a survivor/Canadian-born union rather than a Jewish/non-Jewish one.

And while suburban life was seen as sheltered from the evils that plagued the urban core, a fatal robbery at the local CIBC in 1964-local proprietor Jack Blanc was killed trying to apprehend the robber-shook this idyllic image and had a lasting effect on many families in the area. For some, the Manor was a place to get out of.

These and other stories have started to emerge from our focus group session and conversations with potential donors and oral history candidates. The parallel memories among residents suggest a very tight-knit and communal environment that transcended the decades. Today, the area is still home to a substantial Jewish population alongside significant Italian, Russian, and Filipino populations. According to the 2oir National Household Survey, 4,I60 residents identified as either ethnically or religiously Jewish out of a population of just over 15,000.

Anecdotal evidence suggests that a neighbourhood revival is under way as the grandchildren of original residents move into the area, drawn by the same relatively inexpensive housing and large lots that attracted the first wave of newcomers. Perhaps the OJA's collection development project will reveal new Jewish settlement stories of Bathurst Manor. 